\title{
Analysis Factor Initiated Early Breastfeeding, Husband Support and Promotion of Formula Milk to Failure of Exclusive Breastfeeding
}

\author{
(Research Study at Turi Health Center, Lamongan Regency)
}

\author{
Asyaul Wasiah' ${ }^{1}$, Koesnadi $^{2}$, \\ Indasah $^{2}$ \\ ${ }^{1}$ Magister of Health Study \\ Program of Institut Ilmu \\ Kesehatan STRADA Indonesia \\ ${ }^{2}$ Lecturer of Institut Ilmu \\ Kesehatan STRADA Indonesia \\ Email: \\ arsyilahasna5@gmail.com
}

Received : October 12, 2019

Accepted : February 13, 2020

Published : May 11, 2020

\begin{abstract}
Various studies show that the coverage of exclusive breastfeeding in Indonesia is still very low. Exclusive breastfeeding is very important for the survival of the baby because it contains growth factors and antibody substances. If breast milk is not given exclusively, the immune system's maturation process will be disrupted and cause the baby to get infected easily. The purpose of this study was to find out the most dominant factors affecting the failure of exclusive breastfeeding at Turi Health Center, Lamongan Regency. This research is descriptive descriptive analysis with cross sectional design. A sample of 132 mothers who have babies aged 6-12 months with the Simple Randem Sampling technique, questionnaire instruments, data analysis with the Logistic Regression test. Most of the mothers did not initiate early breastfeeding, namely $78(59.1 \%)$, got enough husband support 80 respondents $(60.6 \%)$ and interested in promoting formula milk as many as 74 respondents $(56.1 \%)$. For partial test Early breastfeeding initiation has a Sig 0.003 value, husband's support for Sig 0.004 and promotion of formula milk Sig 0.001. The results of the analysis of the most dominant variable on the failure of Exclusive ASI were husband's support with a value of OR 1.868. It is expected to increase counselin $g$ and information about the Initiation of Early Breastfeeding and Exclusive Breastfeeding for pregnant women and mothers having babies. As well as being more selective in accepting all forms of promotion of formula milk from various promotional media.
\end{abstract}

Keywords: Exclusive breastfeeding, Nursing mothers, Husband 


\section{INTRODUCTION}

World Health Organisation (WHO) recommends that breastfeeding be carried out exclusively from birth to six months old baby. These recommendations have been followed by various countries in the world, one of them is Indonesia. Although exclusive breastfeeding has been recommended by the government, the failure of exclusive breastfeeding is very common in Indonesia.

Based on data from the Ministry of Health of the Republic of Indonesia in 2017 the percentage of infants receiving exclusive breastfeeding until the age of 6 months was $34.92 \%$. Referring to the 2016 strategic plan target of $42 \%$, the coverage of exclusive breastfeeding for infants younger than six months for East Java Province is still less than the target. In Lamongan Regency, in 2017 the number of infants was 18,542 while those who were given exclusive breastfeeding amounted to 13,600 babies (73.3\%). The lowest coverage was Turi Health Center, out of 446 infants aged 0-6 months, only 94 babies received exclusive breastfeeding with coverage of $22.0 \%$.

Exclusive breastfeeding is a behavior, according to Lawrence Green's behavioral theory, there are three factors that can shape behavior namely predisposing factors, enabling factors, and driving factors. Predisposing factors manifest in socio-demographic factors, such as employment status and income. Enabling factors materialize in facilities that can enable behavior change. The facilities in question are such as a place of birth (nursing care) and the availability of breastfeeding space in the workplace. Meanwhile, motivating factors are manifested in the thoughts of other people who are considered influential, for example health workers who provide information related to Early Breastfeeding Initiation (IMD), exclusive breastfeeding and husband's support (Wendiranti, 2017).

The initiation of Early Breastfeeding in 30 minutes after giving birth has a profound effect on the establishment and duration of breastfeeding. Syafiq's 2012 study explained that mothers who breastfeed in the first hour have a 2 to 8 times greater chance of giving exclusive breastfeeding for up to four months compared to those who don't. However, the fact that there is rarely a place of delivery to do so is that it becomes a means for formula milk producers to market their products. Family support is needed, especially for husbands in the success of exclusive breastfeeding.

Health workers play an important role in supporting the success of exclusive breastfeeding so efforts need to be made including counseling for mothers during pregnancy about early breastfeeding initiation preparation, exclusive breastfeeding involving mothers' husbands so that their knowledge increases and there is no failure of exclusive breastfeeding.

\section{METHODS}

The design of this research is analytical descriptive by using a cross sectional study design (cross sectional study), where researchers study the relationship between independent variables and dependent variables by making instant measurements, not all research objects must be examined on the same day or at the same time but only one variable effect times only (Siregar, 2012). The place and time of this research was carried out on December 14 to 31, 2018 at the Turi Health Center, Lamongan Regency. Independent variables (Early Breastfeeding Initiation, husband support and formula milk promotion), dependent variable (Exclusive breastfeeding failure). The population of mothers who have 6-12 months babies is 196 people. The number of samples is 132 respondents with the technique of Simple random sampling. The instrument in this study used a questionnaire sheet. Data analysis with Logistic Regression and has passed the ethical test.

\section{RESULTS}

Table 4.1 Frequency distribution of Early Breastfeeding Initiation History

\begin{tabular}{cccc}
\hline No & Early Breastfeeding Initiation & Frekuensi (n) & Prosentase (\%) \\
\hline 1 & No Early Breastfeeding Initiation & 78 & 59,1 \\
2 & Early Breastfeeding Initiation & 54 & 40,9 \\
& Total & 132 & 100 \\
\hline
\end{tabular}

Source: Primary Data from 2018 Research Results

Based on Table 4.1 shows that out of 132 respondents most of the mothers did not initiate early breastfeeding, namely $78(59.1 \%)$. 
Table 4.2 Frequency distribution of Husband Support

\begin{tabular}{cccc}
\hline No & Husband support & Frekuensi (n) & Prosentase $(\%)$ \\
\hline 1 & Less & 5 & 3,8 \\
2 & Enough & 80 & 60,6 \\
3 & Good & 47 & 35,6 \\
& Total & 132 & 100 \\
\hline
\end{tabular}

Source: Primary Data from 2018 Research Results

Based on Table 4.2 shows that out of 132 respondents most of the mothers got enough husband support, namely 80 respondents $(60.6 \%)$.

Table 4.3 Frequency distribution of promotion of formula milk

\begin{tabular}{cccc}
\hline No & $\begin{array}{c}\text { Promotion of } \\
\text { formula milk }\end{array}$ & Frekuensi (n) & Prosentase (\%) \\
\hline 1 & Interest & 74 & 56,1 \\
2 & No interest & 58 & 43,9 \\
& Total & 132 & 100 \\
\hline
\end{tabular}

Source: Primary Data from 2018 Research Results

Based on Table 4.3 shows that out of 132 respondents most of the mothers were interested in promoting formula milk as many as 74 respondents $(56.1 \%)$.

Table 4.4 Distribution of Exclusive Breastfeeding failures

\begin{tabular}{cccc}
\hline No & $\begin{array}{c}\text { Exclusive } \\
\text { Breastfeeding } \\
\text { failures }\end{array}$ & Frekuensi (n) & Prosentase (\%) \\
\hline 1 & Failure & 85 & 64,4 \\
2 & Exclusive & 47 & 35,6 \\
& Breastfeeding & & 100 \\
\hline & Total & 132 & \\
\hline
\end{tabular}

Source: Primary Data from 2018 Research Results

Based on Table 4.4 shows that out of 132 respondents most of the mothers failed Exclusive Breastfeeding as many as 85 respondents $(64.4 \%)$.

Table 4.15 Cross Tabulation Initiation of Early Breastfeeding with Exclusive ASI Failure

\begin{tabular}{|c|c|c|c|c|c|}
\hline & & & $\begin{array}{r}\text { Exclusive } \\
\text { fa }\end{array}$ & $\begin{array}{l}\text { Breastfeeding } \\
\text { lures }\end{array}$ & Total \\
\hline & & & failures & $\begin{array}{l}\text { Exclusive } \\
\text { Breastfeeding }\end{array}$ & \\
\hline Initiation of & No & Count & 74 & 4 & 78 \\
\hline Early & IMD & Total (\%) & $94,9 \%$ & $5,1 \%$ & $100 \%$ \\
\hline Breastfeeding & IMD & Count & 11 & 43 & 54 \\
\hline & & Total (\%) & $20,4 \%$ & $79,6 \%$ & $100 \%$ \\
\hline Total & & Count & 85 & 47 & 110 \\
\hline & & Total \% & $64,4 \%$ & $35,6 \%$ & $100.0 \%$ \\
\hline & & $X^{2}=77,24$ & alue $=0,000$ & & \\
\hline
\end{tabular}

Based on table 4.15, it shows that out of 132 respondents almost all of the mothers who did not initiate Early Breastfeeding Initiation failed in Exclusive Breastfeeding, which was 74 (94.9\%). 
Table 4.16 Cross Tabulation of Husband Support with Exclusive ASI Failure

\begin{tabular}{|c|c|c|c|c|c|}
\hline & & & $\begin{array}{r}\text { Exclusive } \\
\text { fai }\end{array}$ & $\begin{array}{l}\text { 3reastfeeding } \\
\text { lures }\end{array}$ & Total \\
\hline & & & failures & $\begin{array}{l}\text { Exclusive } \\
\text { Breastfeeding }\end{array}$ & \\
\hline Husband & Less & Count & 5 & 0 & 5 \\
\hline support & & Total $(\%)$ & $100 \%$ & $0 \%$ & $100 \%$ \\
\hline & Enough & Count & 75 & 5 & 80 \\
\hline & & Total $(\%)$ & $93,8 \%$ & $6,3 \%$ & $100 \%$ \\
\hline & Good & Count & 5 & 42 & 47 \\
\hline & & Total $(\%)$ & $10,6 \%$ & $89,4 \%$ & $100 \%$ \\
\hline Total & & Count & 85 & 47 & 132 \\
\hline & & Total $\%$ & $64,4 \%$ & $35,6 \%$ & $100.0 \%$ \\
\hline
\end{tabular}

Based on table 4.16, it shows that out of 132 respondents, the majority of respondents who received support from their husbands simply failed to provide exclusive breastfeeding, namely 75 respondents $(93.8 \%)$.

Table 4.17 Cross Tabulation of formula milk promotion with Exclusive ASI Failure

\begin{tabular}{|c|c|c|c|c|c|}
\hline & & & $\begin{array}{r}\text { Exclusive } 5 \\
\text { fai }\end{array}$ & $\begin{array}{l}\text { reastfeeding } \\
\text { ures }\end{array}$ & Total \\
\hline & & & failures & $\begin{array}{l}\text { Exclusive } \\
\text { Breastfeeding }\end{array}$ & \\
\hline formula milk & Interest & Count & 69 & 5 & 74 \\
\hline promotion & & Total (\%) & $93,2 \%$ & $6,8 \%$ & $100 \%$ \\
\hline & & Count & 16 & 42 & 58 \\
\hline & interest & Total (\%) & $27,6 \%$ & $72,4 \%$ & $100 \%$ \\
\hline Total & & Count & 85 & 47 & 132 \\
\hline & & Total $(\%)$ & $64,4 \%$ & $35,6 \%$ & $100.0 \%$ \\
\hline & & $X^{2}=61,1$ & $p$ value $=0,000$ & & \\
\hline
\end{tabular}

Based on table 4.17, it shows that out of 132 respondents most of the respondents who were interested in promoting formula milk failed to provide Exclusive Breastfeeding, which was 69 respondents $(93.2 \%)$.

The results of the Logistic Regression Analysis partial test showed the following values: Variable Initiation of early breastfeeding had a Sig Wald value of $0.003<0.05$ so that it refused H0 or which means early breastfeeding initiation had a significant partial effect on the failure of exclusive breastfeeding. The husband's support variable has a Sig Wald value of $0.004<0.05$ so that it rejects H0 or which means husband's support has a significant partial effect on the failure of exclusive breastfeeding. The formula milk promotion variable has a Wald Wald value of $0.001<0.05$ so that it rejects $\mathrm{H} 0$ or which means the promotion of formula milk has a significant partial effect on the failure of exclusive breastfeeding.

The magnitude of the effect is indicated by the EXP value (B) or also called ODDS RATIO (OR). Early Initiation Breastfeeding Variables with OR 1,271, the mothers who did not initiate Early Breastfeeding were more at risk of failing exclusive breastfeeding as much as 1,271 fold. Value $\mathrm{B}=$ Natural Logarithm of $1,271=, 367$. Because the value of $B$ is positive, the mother who does not initiate early initiation has a positive relationship with the failure of exclusive breastfeeding.

Variable husband support with OR 1,868, mothers who lack support from their husbands are more at risk of failing exclusive breastfeeding as much as 1,868 times. Value $\mathrm{B}=$ Natural Logarithm of $1,868=, 625$. Because the value of $B$ is positive, the lack of husband's support has a positive relationship with the failure of exclusive breastfeeding. Variable promotion formula milk with OR 1.071, mothers who are interested in promoting formula milk are at risk of failing exclusive breastfeeding as much as 1.071 times. Value $\mathrm{B}=, 169$. Because the value of $\mathrm{B}$ is positive, the interest in promoting formula milk 
has a positive relationship with the failure of exclusive breastfeeding. Based on the value of EXP (B) or ODDS RATIO (OR), the variable of husband's support greatly influences the failure of Exclusive Breastfeeding.

\section{DISCUSSION}

\section{Effect of Early Breastfeeding Initiation on Failure to Give Exclusive Breastfeeding.}

Based on the results of the logistic regression test analysis obtained $p$ value $0.003<\alpha=0.05$. The results showed that 85 respondents $(64.4 \%)$ respondents who failed to provide exclusive breastfeeding, 11 respondents (20.4\%) succeeded in conducting an IMD, 74 respondents $(94.9 \%)$ did not conduct an IMD. As for 47 respondents (32.8\%) respondents who succeeded in giving exclusive breastfeeding, 43 respondents $(79.6 \%)$ succeeded in IMD and 4 respondents (5.1\%) did not do IMD.

The results of the study conducted by Nurlaili (2014) stated that of 45 respondents $(67.3 \%)$ respondents who failed to provide exclusive breastfeeding, 5 respondents (20\%) succeeded in carrying out IMD, 40 respondents $(95.2 \%)$ did not do IMD , As for 22 respondents (32.8\%) respondents who succeeded in giving exclusive breastfeeding, 20 respondents $(80 \%)$ succeeded in IMD and 2 respondents $(4.8 \%)$ did not do IMD.

According to Fikawati, 2012 Factors Causing Exclusive Breastfeeding Failure are caused by several factors. Among other things, the mothers felt their milk was lacking, the causes were more psychological. Namely, the mother feels that breastmilk production is lacking, when in fact it can meet the needs of the baby. The mother's impatience can actually be overcome by being motivated so that the mother is more convinced that she can produce milk according to the baby's needs.

To support the success of lactation, babies should be breastfed immediately or as early as possible after birth. But not all deliveries go normally and not all can be carried out early breastfeeding. IMD is called early initation or the onset of early breastfeeding, ie the baby starts breastfeeding itself immediately after birth. The success of IMD practices can help so that the exclusive breastfeeding process is successful, whereas if the IMD fails, it will also be a cause for the failure of Exclusive ASI (Roesli, 2013).

The initiation of early breastfeeding is one of the very important starting points for determining breastfeeding success because as early as possible the baby suckles the milk production also increases and the nutritional needs of the baby are fulfilled so the possibility of failure to give exclusive breastfeeding is even lower and even none.

\section{Effect of Husband's Support on Failure to Give Exclusive Breastfeeding.}

Based on the results of the analysis of the data obtained $p$ value $0.0004<\alpha=0.05$. The results of the research conducted at Turi Puskesmas showed that 85 respondents $(64.4 \%)$ respondents who failed to provide exclusive breastfeeding, 5 respondents (100\%) received less husband's support, 75 respondents $(93.8 \%)$ had enough husband support, . 5 respondents $(10.6 \%)$ received good husband support. As for 47 respondents $(35.6 \%)$ respondents who succeeded in giving exclusive breastfeeding, 0 respondents received less support from their husbands, 5 respondents $(6.3 \%)$ had enough support from their husbands. 42 respondents $(89.4 \%)$ received good husband support.

The results of this study are supported by several previous research results such as the research conducted by Suharti (May, 2018) which showed a significant relationship between husband's support and the failure of exclusive breastfeeding in Ranotana Weru Puskesmas, out of 70 respondents with good husband support there were 29 respondents not exclusively giving ASI, 41 respondents gave exclusive breastfeeding. And as many as 33 respondents with less husband support, 27 respondents did not give exclusive breastfeeding and gave exclusive breastfeeding as many as 6 people,

The provision of exclusive breastfeeding does not only rely on knowledge and positive attitudes. The availability of facilities and the time to give breast milk to infants is another thing that needs to be considered. The amount of family intervention in baby care also affects the mother in this exclusive breastfeeding practice.

This shows that fathers play an important role in whether or not breastfeeding is successful and increase breastfeeding rates. Observational data indicate that fathers have an important role in the mother's decision on how to feed babies and mothers who choose to give bottle milk or breastfeeding for a shorter time when the father does not support. 
Family, besides being able to be a supporting factor at the same time can be a limiting factor The mother's desire to provide exclusive breastfeeding should be discussed with the family, especially those who will live with the mother when the baby is born, for example a husband, mother, mother-in-law long before the baby is born or at least during the pregnancy phase. Instill in the family the importance of breastfeeding, how to give exclusive breastfeeding and what support they can provide.

\section{The Effect of Formula Milk Promotion on Failure to Give Exclusive Breastfeeding}

Based on the results of data analysis obtained $p$ value $0.001<\alpha=0.05$. The results of the research conducted at the Turi Puskesmas showed that 85 respondents $(64.4 \%)$ respondents who failed to provide exclusive breastfeeding, 69 respondents (93.2\%) were interested in promoting formula milk, 16 respondents $(27.6 \%)$ were not interested with promotion of formula milk. As for 47 respondents (35.6\%) respondents who succeeded in giving exclusive breastfeeding, 5 respondents $(6.8 \%)$ were interested in promoting formula milk, 42 respondents $(72.4 \%)$ were not interested in promoting formula milk

According to a study from Fikri Ulil Albab 2013 families who were exposed to formula milk promotions tended to experience dysfunctional family decision-making in exclusive breastfeeding, which amounted to $78.9 \%$ compared to families that were not exposed to formula milk promotion at only $57.1 \%$.

Promotion of formula milk is an information dissemination of formula milk products to influence and remind target markets or families to be willing to accept, buy and be loyal to the products offered. Based on the results of the study, from Mifbakhuddin (2015) showed that more than 50\% or as many as 19 respondents $(57.6 \%)$ were exposed to promotion of formula milk, while as many as 14 respondents (42.4\%) were not exposed to promotion of formula milk. This happened because the promotion of formula milk was disseminated through various communication media.

Stimulation of formula milk promotion through various promotional media can form an attitude and behavior to make a purchase. If the perception of a quality product is getting stronger, it will strengthen the attitude that will affect the intention to buy the product and ultimately change the positive behavior towards the negative by not giving exclusive breastfeeding to the baby.

The media on sales promotion and direct marketing have a high level of exposure, which proves that the public is interested in the promotion of product sales through giving discounts, coupons, discounts and product samples that are easily found in kiosks, shops or supermarkets in various places. through public relations more worrying, because producers directly market their products to mothers.

\section{The dominant factor influences the failure of exclusive breastfeeding}

The most dominant variable on the failure of Exclusive Breastfeeding in Turi Lamongan Community Health Center is husband's support with EXP (B) or ODDS RATIO (OR) value which is 1,868 , meaning that mothers who lack husband support are more at risk of failing 1,868 times exclusive breastfeeding

The results of the research conducted at the Turi Puskesmas showed that 85 respondents (64.4\%) respondents who failed to provide exclusive breastfeeding, 75 respondents $(93.8 \%)$ had enough husband support. Whereas from 47 respondents $(35.6 \%)$ respondents who succeeded in giving exclusive breastfeeding, 42 respondents (89.4\%) received good husband support of the 4 types of husband support that were most answered with the correct answers by respondents were emotional or psychological support in the form of husbands guarding their feelings by showing friendliness, husbands giving motivation to mothers to breastfeed their babies, husbands reminding mothers when breastfeeding. In addition, at the Turi Health Center, Lamongan has applied husband's assistance to each mother

The success of breastfeeding in infants is determined by the role of the family, especially the husband. The respondents' husbands in this study were mostly high school educated, according to Notoatmodjo (2012), the higher a person's education, the easier it is to receive information so that more knowledge is also possessed. Conversely, less education will hinder attitudes towards newly introduced values, including regarding Exclusive Breastfeeding.

The work of the respondents' husbands in this study mostly worked private. According to Friedman 2012, the higher the economic level of a person, he will usually be more responsive to the primary needs of his family, especially the needs needed by mothers to give exclusive breastfeeding. 
The results of the study from Hanulan Septiani (2017) found that family support was significantly related to exclusive breastfeeding, where mothers who received family support had a chance of 7.6 times to give exclusive breastfeeding compared to mothers who did not receive support from the family.

Emotional or psychological support is a form of support that makes a mother feel comfortable, confident, cared for. Husband's support is one source of support from the family that cannot be underestimated, because it has a positive effect on nursing mothers. The father's most important role is to create a conducive atmosphere and situation that allows breastfeeding to run smoothly (Friedman, 2010).

One of the factors that influence the success or failure of exclusive breastfeeding is husband's support. Of all the support for nursing mothers the support of the father is the support that means the most to the mother. Father can play an active role in the success of exclusive breastfeeding by providing emotional support and practical assistance. To raise a baby, there is still much needed besides breastfeeding such as snatching a baby, carrying and calming anxious babies, changing diapers, bathing babies, carrying babies to walk in the park, giving milk, and massaging babies. Except for breastfeeding all the tasks can be done by the father.

Fathers who play a role in supporting mothers so that breastfeeding is often called the father's breastfeeding. Basically a thousand breastfeeding mothers may not be more than ten of them can not breastfeed their babies for physiological reasons. So, most mothers can breastfeed well. It's just that they adhere to exclusive breastfeeding for 4-6 months and continue for up to two years which may not be fulfilled thoroughly. That is why the encouragement of fathers and other relatives is needed to increase the mother's confidence in the ability to breastfeed perfectly is husband's support.

\section{CONCLUSION}

There is the influence of Early Breastfeeding Initiation, husband's support and promotion of formula milk for the failure of exclusive breastfeeding. The magnitude of the effect for the Early Breastfeeding Initiation variable was OR 1.271, the husband's support variable was OR 1.868, and the formula milk promotion variable was OR 1.071. It is hoped that we will improve counseling and provide information about Early Breastfeeding Initiations and the benefits of exclusive breastfeeding early to pregnant women and mothers who have babies. As well as being more selective in receiving information on formula milk and not necessarily accepting all forms of promotion of formula milk from various promotional media.

\section{REFERENCES}

Fikawati S dan Syafiq A. 2012. Kajian Implementasi dan Kebijakan Air Susu Ibu Eksklusif dan Inisiasi Menyusui Dini di Indonesia. Makara Indonesia, 14 (1): 17-24, Juni 2012

Fikri Ulil Albab, dkk. 2013. Hubungan Promosi Susu Formula dengan Pengambilan Keputusan Keluarga. Universitas Jember

Friedman MM., BowdenV., Jones E. 2013. Keperawatan Keluarga, Riset, Teori dan Praktik Ed. 5. EGC, Jakarta

Friedman, M. M., Bowden, V. R., dan Jones,E.G. 2010. Buku Ajar Keperawatan keluarga: Riset,Teori \& Praktik. Alih bahasa oleh Achir Yani S, et al. EGC, Jakarta.

Hanulan Septiani, dkk. 2017. Jurnal Aisyah, Jurnal Ilmu Kesehatan, Faktor-Faktor yang Berhubungan dengan Pemberian ASI Eksklusif Oleh Ibu Menyusui yang Bekerja Sebagai Tenaga Kesehatan. $159-174$

Handayani, 2016. Analisis Faktor-faktor yang mempengaruhi IMD, Jurnal Kesehatan STIKes Prima Nusantara Bukittinggi, Vol. 7 No. 1

Notoatmojo S. 2012. Metodologi Penelitian Kesehatan. Rineka Cipta, Jakarta

Nurlaili. 2014. Health psychology biopsychological interaction (8th ed.). Wiley, New York 
Roesli Utami. 2013. Panduan Konseling Menyusui. Pustaka Bunda, Jakarta.

Suharti JF, dkk. 2018. e-Journal Keperawatan (eKp), Hubungan dukungan keluarga dengan pemberian ASI Eksklusif, Volume 6 Nomor 1

Wendiranti Catra Ibriza, dkk. 2017. Journal of Nutrition College, Faktor Resiko Keggalan ASI Eksklusif. 2337-6236 